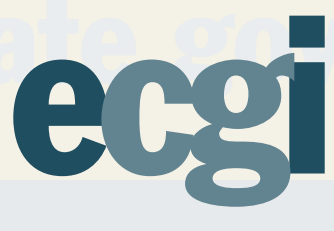

\title{
Sustainable Finance and Stewardship: Unlocking Stewardship's Sustainability
}

Law Working Paper N 521/2020

May 2020
Dionysia Katelouzou

Kings College London

Alice Klettner

University of Technology Sydney

(C) Dionysia Katelouzou and Alice Klettner 2020. All rights reserved. Short sections of text, not to exceed two paragraphs, may be quoted without explicit permission provided that full credit, including (C) notice, is given to the source.

This paper can be downloaded without charge from: http://ssrn.com/abstract_id=3578447

https:/ecgi.global/content/working-papers 
ECGI Working Paper Series in Law

\title{
Sustainable Finance and Stewardship: Unlocking Stewardship's Sustainability Potential
}

\author{
Working Paper $N^{\circ} 521 / 2020$ \\ May 2020 \\ Dionysia Katelouzou \\ Alice Klettner
}

(C) Dionysia Katelouzou and Alice Klettner 2020. All rights reserved. Short sections of text, not to exceed two paragraphs, may be quoted without explicit permission provided that full credit, including $(\mathbb{C}$ notice, is given to the source. 


\begin{abstract}
This paper explores the role of investor stewardship against a background of broader efforts to improve the sustainability of financial markets. Stewardship codes, encouraging institutional investors to act as long-term, responsible shareholders, comprise an emerging aspect of contemporary corporate governance frameworks with important implications for sustainable finance. They have the potential to promote the incorporation of environmental, social and governance (ESG) factors into both financial and business decision-making. This paper examines the way in which 25 stewardship codes from across the world approach ESG integration and explores the possibilities for enhancing their impact on sustainability. It concludes that stewardship codes form an influential part of the overall network of regulatory instruments supporting sustainable finance. They help to secure transparency, accountability and a progressive interpretation of long-standing fiduciary duties that better balances the interests of all stakeholders.
\end{abstract}

Keywords: institutional investors, stewardship codes, sustainable finance, ESG, fiduciary duties, transparency, accountability, corporate governance

JEL Classifications: G23, G30, G32, K22, N20, M14

\author{
Dionysia Katelouzou* \\ Senior Lecturer \\ Kings College London, The Dickson Poon School of Law \\ Somerset House East Wing, Strand \\ London WC2R 2LS, United Kingdom \\ e-mail: dionysia.katelouzou@kcl.ac.uk
}

Alice Klettner

Senior Lecturer

University of Technology Sydney Business School

Tower Building 1, Level 20, 15 Broadway

Ultimo NSW 2007, Australia

e-mail: Alice.Klettner@uts.edu.au

${ }^{*}$ Corresponding Author 


\title{
Sustainable Finance and Stewardship: \\ Unlocking Stewardship's Sustainability Potential
}

Dionysia Katelouzou* \& Alice Klettner**

May 2020 Draft

An edited version of the paper will be published as a chapter in Global Shareholder Stewardship: Complexities, Challenges and Possibilities (Dionysia Katelouzou \& Dan W. Puchniak eds, Cambridge University Press, Forthcoming)

\begin{abstract}
This paper explores the role of investor stewardship against a background of broader efforts to improve the sustainability of financial markets. Stewardship codes, encouraging institutional investors to act as long-term, responsible shareholders, comprise an emerging aspect of contemporary corporate governance frameworks with important implications for sustainable finance. They have the potential to promote the incorporation of environmental, social and governance (ESG) factors into both financial and business decision-making. This paper examines the way in which 25 stewardship codes from across the world approach ESG integration and explores the possibilities for enhancing their impact on sustainability. It concludes that stewardship codes form an influential part of the overall network of regulatory instruments supporting sustainable finance. They help to secure transparency, accountability and a progressive interpretation of long-standing fiduciary duties that better balances the interests of all stakeholders.
\end{abstract}

Keywords: institutional investors, stewardship codes, sustainable finance, ESG, fiduciary duties, transparency, accountability, corporate governance 


\section{INTRODUCTION}

Across the world, policymakers are grappling with how to improve the sustainability of financial markets. Challenges include addressing the root causes of short-termism; correcting the failure of corporations and investors to manage the financial risks associated with climate change, social inequality and economic degradation; and mobilising business to support sustainable development. The Covid-19 pandemic has added to these challenges, yet also provides an opportunity to reassess the purpose of financial markets and their role in social and economic recovery. ${ }^{1}$ With some of the largest corporations and investment managers, such as Blackrock, already taking an increased focus on sustainability and driving change on environmental issues, human rights, stakeholder engagement and transparency, 'a fundamental reshaping of finance ${ }^{2}$ is taking place. At the same time, the responsibilities of the business corporation and its obligations towards civil society are at the centre of policy fights and heated public debates prompting a paradigmatic shift in the way we understand corporate governance today. ${ }^{3}$ The era of shareholder-oriented corporate governance with corporate purpose confined to profit maximisation is at an end, while shifting perceptions regarding the role and obligations of the business corporation and its key actors in different social contexts are reflections of changes in a wider ranging debate over the governance of economic markets. ${ }^{4}$

\footnotetext{
* Senior Lecturer, The Dickson Poon School of Law, King's College London

** Senior Lecturer, Business School, University of Technology Sydney
}

\footnotetext{
${ }^{1}$ See e.g. Andrew Hill, The business of saving the world, Financial Times, 28 April 2020; CB Bhattacharya, How the great Covid-19 reset can help firms build a sustainable future, World Economic Forum, 15 May 2020, <https://www.weforum.org/agenda/2020/05/the-covid-19-reset-sustainability/> accessed 22 May 2020. 2 Letter from Larry Fink to CEOs of listed companies 2020 <https://www.blackrock.com/corporate/investorrelations/larry-fink-ceo-letter> accessed 4 March 2020.

${ }^{3}$ See e.g. Martin Lipton, 'Corporate Governance: The New Paradigm', Harvard Law School Forum on Corporate Governance, 11 January 2017, <https://corpgov.law.harvard.edu/2017/01/11/corporate-governancethe-new-paradigm/> accessed 1 February 2020; Colin Mayer, 'The Future of the Corporation: Towards Humane Business' British Academy Project, 11 October 2018,

<https://www.wlrk.com/docs/TheFutureoftheCorporationTowardsHumaneBusiness.pdf > accessed 5 March 2020; Dionysia Katelouzou 'Reflections on the Nature of the Public Corporation in an Era of Shareholder Activism and Stewardship' in Understanding the Company: Corporate Governance and Theory, Barnali Choudhury and Martin Petrin eds. (CUP, 2018), 117-144; Dionysia Katelouzou \& Peer C Zumbansen, 'Transnational Corporate Governance: The State of the Art and Twenty-First Century Challenges' (2020) TLI Think! Paper 06/2020, <https://ssrn.com/abstract=3536488> accessed 5 March 2020.

${ }^{4}$ Paddy Ireland, 'Financialization and corporate governance' (2009) 60(1) Northern Ireland Legal Quarterly 1; Paddy Ireland, 'Efficiency or Power? The Rise of the Shareholder-oriented Joint Stock Corporation' (2018) 25(1) Indiana Journal of Global Legal Studies 291. See also the contributions to Jean-Philippe Robé, Antoine Lyon-Caen \& Stéphane Vernac, Multinationals and the Constitutionalization of the World Power System (Routledge, 2016)
} 
It is within this context that corporate governance and company law debates are fusing with increasing claims of sustainability, the latter being defined as the deployment of business and finance in a manner that protects the stability and resilience of the environment, facilitates social justice and promotes long-term economic prosperity securing the 'social foundation' of humanity without further degradation of the 'planetary boundaries'. ${ }^{5}$ This Chapter explores the role of an emerging, but important aspect of contemporary corporate governance, that of investor stewardship, within this integrated framework of sustainability. It assesses the potential for stewardship codes to support and encourage investment behaviour that promotes the long-term viability of environmental, social and economic welfare, thereby contributing towards the sustainability of the financial system as a whole.

If we view investor stewardship as long-term, responsible ownership of shares and more recently of other assets, ${ }^{6}$ there is certainly potential for investors to steer investee companies towards a more sustainable path. However, investors sit within a financial system that presents many different market incentives that can interfere with this common-sense mission. ${ }^{7}$ Institutional investors, such as large pension funds, often act as intermediaries between fund beneficiaries and asset managers meaning that their role as shareholders is less direct than might be imagined. They operate within a legal framework of fiduciary duties, reporting requirements and contractual mandates that set the boundaries for their approach towards sustainability. In this Chapter we argue that the recent development of stewardship codes across the world, as one aspect of a broader emerging socially-oriented regulatory framework aimed at promoting the incorporation of environmental, social and governance (ESG) into business decision-making, has the potential to influence investors' choices and effect changes to enable the transition to sustainable finance. We explore both the potential and challenges for stewardship codes as a tool for improving the sustainability of finance and we argue that these codes are a valuable element of an emerging international network of regulatory measures that provides a powerful pathway for change. Although much of this network is based on voluntary

\footnotetext{
${ }^{5}$ Beate Sjafjell and Christopher M Bruner, 'Corporations and Sustainability' in Beate Sjafjell and Christopher M Bruner (eds) The Cambridge Handbook of Corporate Law, Corporate Governance and Sustainability (CUP, 2019), 3, 7-10.

${ }^{6}$ For this extension, see Financial Reporting Council, UK Stewardship Code 2020, <https://www.frc.org.uk/getattachment/5aae591d-d9d3-4cf4-814a-d14e156a1d87/Stewardship-Code_Dec-19Final-Corrected.pdf > accessed 12 February 2020.

${ }^{7}$ See e.g. Dirk Schoenmaker \& Willem Schramade, 'Investing for long-term value creation' (2019) 9(4) Journal of Sustainable Finance \& Investment 356.
} 
initiatives, it taps into hard legal rules (across contract, trust, corporate and tort law) ${ }^{8}$ which often provide confusing or even contradicting messages about the extent to which sustainability concerns can be integrated into investment decision-making. Stewardship codes, we argue, can untangle this complex nexus and unlock sustainable finance in at least two ways. First, by supporting a progressive interpretation of the legal duties of pension fund trustees and company directors, stewardship codes can help harness the financial clout of large investors in order to steer business towards a more sustainable future. ${ }^{9}$ Secondly, stewardship codes have the potential to infiltrate the complex modern investment chain to reach service providers and financial intermediaries that have so far been hidden from view, extending the influence of those who think to the long-term. Not all stewardship codes currently grasp this full potential but as they are revised, updated and strengthened in future we hope that their potential will be further unlocked.

The Chapter proceeds as follows. Part II sets the context by explaining what we mean by sustainable finance and why a transition is deemed necessary. It provides an update on some of the key international initiatives and national policies designed to encourage and promote a more sustainable global finance system. Part III focuses on the role of institutional investors within sustainable finance with a view to promoting stewardship and the incorporation of ESG factors into investment and risk management processes. We look at what sustainable finance means for institutional investors both in a practical and legal sense and we examine whether and how 25 stewardship codes around the world incorporate ESG considerations into their principles. We show that ESG investing is increasingly becoming a core component of stewardship codes, but it is not always expressly connected to hard law fiduciary or other investment management duties and transparency obligations around ESG. In Part IV we take a critical stance on stewardship codes and we explore the possibilities for enhancing their impact in the specific area of sustainable finance. We argue that to unlock additional potential stewardship codes should maximise their scope and influence to encompass as much of the investment chain as possible, and where possible extend the purpose of ESG integration beyond private financial benefit to encompass a much broader public benefit test. In Part V we conclude

\footnotetext{
${ }^{8}$ On the private law governing investment intermediaries in the UK, see e.g. I. H.-Y. Chiu and D. Katelouzou, 'Making a Case for Regulating Institutional Shareholders' Corporate Governance Roles' (2018) Journal of Business Law 67.

${ }^{9}$ They do this both directly, through encouraging fund trustees to consider ESG factors as part of their fiduciary duties to beneficiaries, but also indirectly by encouraging investors to enter into dialogue with companies which then encourages those company directors to consider ESG factors in their decision-making.
} 
that stewardship codes have an important role to play as one of many mutually reinforcing regulatory instruments pursuing the common goal of sustainable development.

\section{SUSTAINABLE FINANCE AND REgUlATORY INITIATIVES TO SUPPORT IT}

\section{A. Definitions and objectives of sustainable finance}

Sustainable finance is part of a broader universe of sustainability efforts, aimed at achieving sustainable development - a concept first defined in the Brundtland Report in 1987 as 'development that meets the needs of the present without compromising the ability of future generations to meet their own needs'. ${ }^{10}$ Today this concept forms the basis of the United Nations (UN) 2030 Agenda for Sustainable Development and its seventeen Sustainable Development Goals (SDGs) which aim to eradicate poverty, protect the planet and promote peace and prosperity for all. ${ }^{11}$ Calls for sustainable development have been generally associated with the corporate social responsibility (CSR) movement. ${ }^{12}$ In most jurisdictions today company directors are expected to take account of environmental and social issues in their decision-making, to the extent that this is in the best interests of the company, and to prepare relevant reports either on a voluntary or mandatory basis. ${ }^{13}$ Yet, it has become obvious in more recent years that the support of the finance sector is also essential in achieving sustainable development, both to facilitate CSR and longer-term value creation as well as to direct finance towards greener and more socially inclusive economic activities. ${ }^{14}$

Definitions of sustainable finance range from very broad ideas around creating a stable and resilient finance system to more narrow definitions of financial decision-making that

\footnotetext{
${ }^{10}$ Report of the World Commission on Environment and Development: Our Common Future, October 1987, $<$ https://sustainabledevelopment.un.org/content/documents/5987our-common-future.pdf $>$ accessed 25 January 2020.

${ }^{11}$ United Nations General Assembly resolution 70/1, Transforming Our World: The 2030 Agenda for Sustainable Development, A/RES/70/1 (25 September 2015).

${ }^{12}$ For earlier literature on CSR see e.g. Amiram Gill, 'Corporate Governance as Social Responsibility: A Research Agenda' (2008) 26 Berkeley J. Int'l L 452. For more recent attempts to widen the CSR scope to address structural gender inequality and colonial dependency in global supply chains, see Banu Ozkazanc-Pan 'CSR as Gendered Neocoloniality in the Global South' (2019) 160 Journal of Business Ethics 851.

${ }^{13}$ See e.g. Andrew Keay, 'Moving Towards Stakeholderism? Constituency Statutes, Enlightened Shareholder Value and More: Much Ado about Little?' (2011) European Business Law Review; Afra Afsharipour 'Redefining Corporate Purpose: An International Perspective' (2016) 40 Seattle University Law Review 466; Florian Möslein and Karsten Sørensen, 'Nudging for Corporate Long-Termism and Sustainability? Regulatory Instruments from a Comparative and Functional Perspective' (2017) 24 Columbia Journal of European Law 391.

${ }^{14}$ Dirk Schoenmaker and Willem Schramade, Principles of Sustainable Finance (OUP 2019).
} 
integrates ESG factors. ${ }^{15}$ The common theme is that financial markets should address the existential challenge of transitioning towards sustainability by looking to the long-term and integrating social and environmental risks and opportunities. If the economy prioritises human well-being, social equity and protection of the environment we can be more confident of longterm health and prosperity for a wider proportion of the population. The EU's Higher Level Expert Group on Sustainable Finance explains:

For the financial system, sustainability has a dual imperative. The first is to ensure that environmental, social and governance (ESG) factors are at the heart of financial decisionmaking. The second is to mobilise capital to help solve society's key challenges that require long-term finance: creating jobs, especially for young people, improving education and retirement finance, tackling inequality, and accelerating the shift to a decarbonised and resource-efficient economy. ${ }^{16}$

Sustainable finance can be seen as a response to ongoing economic crises, social disparities and environmental problems and growing discontentment with the functioning of financial agents. ${ }^{17}$ The 2008 Global Financial Crisis (GFC) revealed the failure of financial systems to take account of systemic risk and the consequent costs for both business and society and brought home the importance of good governance and risk management as well as ability to look to the long-term. For instance, the Kay Review in the UK stressed that the purpose of the equity markets is to support the real economy: to sustain high performing companies and earn good returns for savers without undue risk. ${ }^{18}$ In this context, short-termism and the financialisation of business was seen to have contributed to a decline in the long-term success of many companies. ${ }^{19}$

These economic concerns have coincided with environmental concerns over climate change to create the conditions necessary for coordinated change. The Paris Agreement on Climate Change $\mathrm{e}^{20}$ is one of the major triggers of policy attention in this area as countries contemplate exactly how they will meet agreed targets for reducing carbon-emissions and how

\footnotetext{
${ }^{15}$ See Interim Report of the EU High-Level Expert Group on Sustainable Finance, Financing a Sustainable European Economy, (July 2017), 11, <https://ec.europa.eu/info/sites/info/files/170713-sustainable-financereport en.pdf> accessed 5 March 2020; Dirk Schoenmaker and Willem Schramade, Principles of Sustainable Finance (OUP 2019); Ali M. Fatemi and Iraj J.Fooladi 'Sustainable finance: A new paradigm' (2013) 24 Global Finance Journal 101.

${ }^{16}$ Interim Report (n 14) 8.

${ }^{17}$ Joakim Sandberg, 'Toward a Theory of Sustainable Finance', in Thomas Walker, Stefanie D. Kibsey and Rohan Crichton (eds) Designing a Sustainable Financial System (Palgrave Macmillan, 2018).

${ }^{18}$ John Kay, 'The Kay Review of UK Equity Markets and Long-Term Decision Making' (2012) 14.

19 ibid 18-19.

${ }^{20}$ United Nations, Paris Agreement (adopted 13 December 2015), in UNFCCC, Report of the Conference of the Parties on its Twenty-First Session, Addendum, at 21, UN Doc. FCCC/CP/2015/10/Add. 1 (29 January 2016).
} 
they will align financial flows with a pathway towards climate-resilient development. ${ }^{21}$ The European Commission's Action Plan for Financing Sustainable Growth explains that 'Europe has to close a yearly investment gap of almost EUR 180 billion to achieve EU climate and energy targets by 2030'.22 A 2019 report supported by the Principles for Responsible Investing (PRI) predicts a \$US1.6 trillion repricing in sectors ranging from energy to agriculture. ${ }^{23} \mathrm{As}$ we make the switch to renewable energy, greener construction, sustainable farming methods and more efficient transport there will be massive changes in the value of certain assets and industries. ${ }^{24}$ It is becoming increasingly obvious that ESG factors can no longer be seen as 'non-financial' but have significant financial implications and companies can 'do well by doing good'. ${ }^{25}$ But from the perspective of return on investments, the empirical evidence is more contradictory. While an exhaustive account of the empirical literature on the link between ESG and performance remains out of the scope of this Chapter, it is safe to say that embedded efforts to improve the sustainability of finance can have a positive impact on business performance as well as wider benefit for civil society. ${ }^{26}$

As the SDGs have moved away from the Brundtland approach of 'do no harm', to invoke a proactive need for joint action among corporate actors (including investors) and civil society, there are now significant challenges for companies and investors in actively investing for the SDGs. ${ }^{27}$ One issue is the fact that sustainability has tended to be discussed in a 'weak' form associated with the business case for CSR, which limits CSR to activities that improve long-

\footnotetext{
${ }^{21}$ For a review of the sustainable development provisions of the Paris Agreement, see Marie-Claire Cordonier Segger 'Advancing the Paris Agreement on Climate Change for Sustainable Development' (2016) 5 Cambridge International Law Journal 202. For the implementation risks under the Trump Administration, see Rafael LealArcas and Antonio Morelli 'The Resilience of the Paris Agreement: Negotiating and Implementing the Climate Change' (2018) 31 Georgetown International Environmental Law Review 1.

${ }^{22}$ European Commission, COM(2018)97, Brussels, 8 March 2018.

23 'UN-supported-investor-group-finds-large-gap-between-stock-market-winners-and-losers-from-inevitablepolicy-response-to-climate-change’ (10 December 2019) <https://www.unpri.org/news-and-press/un-supportedinvestor-group-finds-large-gap-between-stock-market-winners-and-losers-from-inevitable-policy-response-toclimate-change/5212.article> accessed 4 March 2020.

${ }^{24}$ International Monetary Fund, Global Financial Stability Report: Lower for Longer, Chapter 6 Sustainable Finance (October 2019); Sonia Labatt and Rodney R. White, Carbon Finance: The Financial Implications of Climate Change, (Wiley 2007).

${ }^{25}$ See e.g. Ali M. Fatemi and Iraj J.Fooladi ‘Sustainable finance: A new paradigm’ (2013) 24 Global Finance Journal 101.

${ }^{26}$ For the mixed evidence on the link between sustainability and investors' performance, see Dionysia Katelouzou and Eva Micheler, 'Stewardship in the UK: The Demand Side' in Dionysia Katelouzou and Dan W. Puchniak (eds), Global Shareholder Stewardship: Complexities, Challenges and Possibilities (CUP 2021 forthcoming)

${ }^{27}$ See e.g. Willem Schramade, 'Investing in the UN Sustainable Development Goals: Opportunities for Companies And Investors’ (2017) 29 J. Applied Corporate Finance 87; Jose Manuel Diaz-Sarachage, Daniel Jato-Espino and Daniel Castro-Fresno, 'Is the Sustainable Development Goals (SDGs) index an adequate framework to measure the progress of the 2030 Agenda?' (2018) 26 Sustainable Development 663.
} 
term financial performance. ${ }^{28}$ These weak CSR initiatives, often confusing sustainability with stakeholder responsiveness, ${ }^{29}$ have failed to address society's bigger problems and the case is now increasingly made for a stronger form of corporate sustainability that accepts a slowing of overall financial growth and promotes cleaner, more equitable growth in both developed and developing nations. ${ }^{30}$

Thus, the overall aims and objectives of sustainable finance include: (i) provision of finance for improving sustainability; (ii) enhancing the overall resilience and stability of the finance system; (iii) improving transparency and information flow to enable better decisionmaking based on incorporation of ESG issues; and (iv) delivering a financial system that meets community and consumer expectations for sustainability. This includes finding and directing the dollars needed to deliver on the UN SDGs and Paris Agreement targets to facilitate the transition to a low-carbon, resource-efficient, socially inclusive economy. The key question, of course, is how to establish sustainable finance and whether law (defined in a broad way to include both national and international instruments, both binding and nonbinding) can contribute to foster it.

\section{B. A snapshot of the institutional framework of sustainable finance}

The governance of sustainable finance is largely fragmented. There are many international, supranational and national initiatives and policies promoting and supporting aspects of sustainable finance. Although they have emerged in a rather uncoordinated fashion, they provide a strong basis for a common understanding around different aspects of sustainable finance and are increasingly being joined together through mutual recognition to form a regulatory network of mostly voluntary standards. ${ }^{31}$ The formal creation of the United Nations Environment Programme Finance Initiative (UNEP FI) in 2003 was a significant milestone in recognising the need for coordinated policy development and UNEP's 2014 'Inquiry: Design

\footnotetext{
${ }^{28}$ Archie B. Caroll and Kareem M Shabana, 'The Business Case for Corporate Social responsibility: A review of Concepts, Research and Practice' (2010) 12 Int'1 J. Mngt. Rev. 85, 86-7. For a recent critique, see Michael L Barnett 'The Business Case for Corporate Social Responsibility: A Critique and an Indirect Path' (2019) Business \& Society 167.

${ }^{29}$ Barnett (n 28).

${ }^{30}$ For the 'stronger' notion of sustainability see the contributions to Sjafjell and Bruner (n 4), and especially for developing countries see, see Alvaro Pereira, An Opportunity for a Sustainable System of Corporate Law and Governance in Latin American (analysing the Pacifil Alliance, an economic bloc formed by Chile, Colombia, Mexico and Peru) 331; Chao Xi, Shareholder Voting and Corporate Sustainability in China, 431; Harpeet Kaur, Achieving Sustainable Development Goals in India, 460; Benedict Sheehy and Cacik Rut Damayati, Sustainability and Legislated Corporate Social Responsibility in Indonesia, 475.

${ }^{31}$ Generally on the role of transnational private regulation, see Kenneth W. Abbott and Duncan Snidal 'Strengthening International Regulation Through Transnational New Governance: Overcoming the Orchestration Deficit' (2009) 42 Vanderbilt Journal of Transnational Law 501.
} 
of a Sustainable Finance System' marked increased efforts towards finding concrete policy options. $^{32}$

Voluntary international initiatives have been leading best practice in the area through a process of private, industry-led governance which is thoroughly distinguished by Thistlewaite from public law. ${ }^{33} \mathrm{He}$ explains how these initiatives support technical consensus-building as well as reflexive learning processes to generate authority and legitimacy around emerging practices. Regulatory scholars have long pointed out this ability of soft law to create learning systems both for the regulator and regulatee. ${ }^{34}$ Perhaps the most well-established international initiative for institutional investors is the PRI, a voluntary and aspirational set of six investment principles aimed at incorporating ESG issues into investment practice. ${ }^{35}$ They were developed by the investment industry with support from the UNEP FI and launched in April 2006. Since then, the number of signatories has grown from 100 to over 2300 representing more than $\$ 83$ trillion of assets across 50 markets. ${ }^{36}$ Although the PRI are very broad in their nature, research has found that they can facilitate the emergence of collective action amongst investors by providing a mobilising structure and normalising the responsible investment ideology. ${ }^{37}$

On the other hand, the PRI have been criticised for their lack of accountability and enforcement which enables them to act as a 'shroud of legitimacy' for traditional nonresponsible investment practices. ${ }^{38}$ To address these shortcomings, the PRI is making efforts to strengthen its accountability by increasing disclosure requirements for signatories based on privately developed standards such as the Task Force on Climate-Related Financial Disclosures (TCFD), set up by the G20's Financial Stability Board. ${ }^{39}$ The TCFD has developed recommendations for voluntary, consistent climate-related financial risk disclosures for use by

\footnotetext{
32 The Inquiry has resulted in many Reports examining different aspects of sustainable finance, available at $<$ https://unepinquiry.org/> accessed 4 March 2020. For a general review see 'Roadmap for a Sustainable Financial System - A UN Environment - World Bank Group Initiative’ (November 2017).

${ }^{33}$ Specifically on the use of 'private environmental governance', see Jason Thistlethwaite, 'Private governance and sustainable finance', (2014) 4 Journal of Sustainable Finance \& Investment, 61.

${ }^{34}$ See e.g. Sharon Gilad, 'It Runs in the Family: Meta-Regulation and Its Siblings' (2010) 4(4) Regulation \& Governance 485; Christine Parker, The Open Corporation: Effective Self-Regulation and Democracy (Cambridge University Press, 2002).

35 The Global compact 'Who Cares Wins: Connecting Financial Markets to a Changing World' (December 2004).

${ }^{36}$ More information is available: <https://www.unpri.org/pri/about-the-pri>_accessed 12 February 2020.

${ }^{37}$ Jean-Pascal Gond and Valeria Piani, 'Enabling Institutional Investors' Collective Action: The Role of the Principles for Responsible Investment Initiative' (2013) 52(1) Business and Society 64.

${ }^{38}$ Taylor Gray, 'Investing for the Environment? The Limits of the UN Principles of Responsible Investment' (2009) <https://papers.ssrn.com/sol3/papers.cfm?abstract_id=1416123> accessed 12 February 2020.

${ }^{39}$ See <https://www.fsb.org/2016/12/recommendations-of-the-task-force-on-climate-related-financialdisclosures/> accessed 12 February 2020.
} 
companies in providing information to investors, lenders, insurers and other stakeholders. ${ }^{40} \mathrm{In}$ February 2019 the PRI announced that reporting against TCFD based indicators would become mandatory in 2020 for its signatories. ${ }^{41}$ A further investor-focused initiative Climate Action $100+$ also supports the TCFD in the context of its mission of pressing for the world's largest corporate greenhouse gas emitters to take necessary action on climate change. ${ }^{42}$ In September 2019 this initiative had 370 signatories representing over \$35 trillion in assets under management. ${ }^{43}$ This mutual recognition of international initiatives has important implications for the building of a regulatory network of private standard-setting and governance on sustainable governance. ${ }^{44}$

As well as these international initiatives, individual nations and regions are taking action on sustainable finance through policy agendas that span a wide range of traditionally separate areas of law and regulation. They target banks, pension funds, insurance, credit rating agencies, regulators, peak bodies and listed companies. For institutional investors, stewardship codes now form part of the framework for sustainable finance in many countries across Europe, Asia, the Americas, Africa and Australasia. ${ }^{45} \mathrm{We}$ discuss their role as national soft law instruments in Parts III and IV below. However, in some countries hard law developments are also emerging, altering the institutional framework for finance in an attempt to improve sustainability. ${ }^{46}$

The European Union has been at the forefront of these developments and EU legislative efforts are now setting a precedent internationally. In late 2016 the Higher Level Expert Group on Sustainable Finance (HLEG) comprising 20 senior experts from civil society, the finance sector and academia was set up to provide advice to the European Commission on how to steer the flow of finance towards sustainable investment and protect the stability of the financial

\footnotetext{
${ }^{40}$ See <https://www.unglobalcompact.org/what-is-gc > accessed 12 February 2020.

${ }^{41}$ See Edward Baker and Senita Galijatovic, FAQ on Mandatory Climate Reporting for PRI signatories, PRI, available: <https://www.unpri.org/reporting-for-signatories/faq-on-mandatory-climate-reporting-for-prisignatories/5356.article $>$ accessed 12 February 2020.

${ }^{42}$ See <http://www.climateaction100.org/> accessed 12 February 2020.

${ }^{43}$ Climate Action 100+ '2019 Progress Report' (September 2019).

${ }^{44}$ Further on transnational private regulation see e.g. Fabrizio Cafaggi, 'Transnational Governance by Contract: Private Regulation and Contractual Networks in Food Safety' in Alex Marx, Miet Maertens, Johan Swinnen and Jan Wouters (eds.) Private Standards and Global Governance (Edward Elgar Publishing, 2012).

${ }^{45}$ See further Dionysia Katelouzou and Dan W. Puchniak 'Introduction to Shareholder Stewardship' in Dionysia Katelouzou and Dan W. Puchniak (eds), Global Shareholder Stewardship: Complexities, Challenges and Possibilities (CUP 2021 forthcoming).

${ }^{46}$ For the hard law aspects of stewardship in the UK, see see Dionysia Katelouzou Institutional Shareholders and Corporate Governance: The Path to Enlightened Stewardship (CUP, 2021 Forthcoming).
} 
system. ${ }^{47}$ Based on the HLEG's recommendations, on 8 March 2018, the European Commission issued its Action Plan on Financing Sustainable Growth, setting out an ambitious agenda of ten action points. ${ }^{48}$ The EU Action Plan recognises that in order for capital to flow towards sustainable activities there has to be a shared understanding of what sustainable means. On 24 May 2018 the Commission issued a proposal for a regulation on the establishment of a framework to facilitate sustainable investment which aims to provide technical definitions of sustainable economic activities (Taxonomy regulation). ${ }^{49}$ This ground-breaking legislation is likely to influence global standards on sustainability and provide opportunities for business involved in climate change mitigation and adaptation; protection of natural resources; waste recycling and pollution prevention. Also of interest in the context of stewardship are the Action Plan's points that relate to the duties of institutional investors (Action 7) and efforts to improve disclosure (Action 9). ${ }^{50}$ These build on earlier legislative efforts to increase the role of institutional investors in corporate governance, particularly the Shareholder Rights Directive II (SRD II) which aims to encourage long-term shareholder engagement in listed companies and improve transparency on shareholder engagement. ${ }^{51}$

National initiatives are underfoot in many countries although most are still at a relatively early stage of policymaking. For instance, the UK government published its Green Finance Strategy in July 2019.52 In Canada an expert panel was set up by the government in April 2018 to engage with business experts around investments that benefit the environment. ${ }^{53}$ In contrast, the United States and Australia both lack a centralised government-led plan for sustainable finance, but state and industry-led action is afoot. In the United States, California has set a target of 50\% renewable energy by 2030 and New York has set up the NY Green Bank to increase investment into clean energy markets. ${ }^{54}$ In Australia, leaders across banking, finance, peak bodies and academia are collaborating as part of the Australian Sustainable Finance

\footnotetext{
${ }^{47} \operatorname{COM}(2016) 0601$.

${ }^{48} \mathrm{COM}(2018) 97$.

${ }^{49} \operatorname{COM}(2018) 0353$.

${ }^{50}$ See further Part III below.

${ }^{51}$ Directive 2017/828/EU of the European Parliament and of the Council of 17 May 2017 amending Directive 2007/36/EC as regards the encouragement of long-term shareholder engagement [2017] OJ L132/1. For an analysis of the stewardship related provisions of the SRD II, see Iris H.-Y. Chiu and Dionysia Katelouzou 'From Shareholder Stewardship to Shareholder Duties: is the Time Ripe?' in Hanne Birkmose (ed.), Shareholders ' Duties (Kluwer Law International, 2017), 131-52.

52 See <https://www.gov.uk/guidance/green-finance> accessed 4 March 2020.

53 The Panel's final report was published in June 2019, see <https://www.canada.ca/en/environment-climatechange/services/climate-change/expert-panel-sustainable-finance.html> accessed 4 March 2020

${ }^{54}$ UNEP, 2016 The State of Sustainable Finance in the United States, Inquiry: Design of a Sustainable Finance System <http://unepinquiry.org/wpcontent/uploads/2016/02/The State of Sustainable Finance in the US.pdf $>$ accessed 12 May 2020.
} 
Initiative to prepare a sustainable finance roadmap to be launched in $2020 .{ }^{55}$ China has a more top-down approach set out in its 2016 'Guidelines for Establishing the Green Financial System' which aims to incentivise more private capital to be directed towards green sectors and away from polluting sectors. ${ }^{56}$

This brief examination of selected international, regional and national initiatives reveals the emerging (albeit fragmented) regulatory network of sustainable finance that is changing prevailing industry norms and expectations. While this list is by no means exhaustive, ${ }^{57}$ each of the initiatives outlined above has individual impact relating to a specific aspect of sustainable finance as well as a cumulative overall effect on the behaviour of organisations within the finance system. This reflects the global nature of finance, particularly for large investors, and the fact that foreign direct investment makes up a large proportion of investment on most stock exchanges. ${ }^{58}$ In terms of policy-making, a trend that is likely to continue, especially in Western nations, is the high involvement and consultation with the private sector as a form of ' $\mathrm{global}$ governance' with or without state intervention. ${ }^{59}$ Sustainable finance strategies hope to mobilise the private sector to support sustainable development whilst at the same time encouraging the mainstreaming of incorporation of ESG into financial decision making. It is this second aim that brings us to consider in more detail the role of institutional investors and stewardship in sustainable finance.

\section{InSTITUTIONAL INVESTORS, SUSTAINABILITY AND STEWARDSHIP}

As introduced above, institutional investors and the investment industry are a key focus of sustainable finance policy. In this Part we examine the practicalities of sustainable finance for institutional investors. We introduce the key strategies for sustainable investing and how they currently interact with both: (i) hard law, primarily investors' legal duties and reporting requirements; and, (ii) soft law in the form of stewardship codes.

\footnotetext{
${ }^{55}$ See <https://www.sustainablefinance.org.au/> accessed 4 March 2020.

${ }^{56}$ See <http://www.pbc.gov.cn/english/130721/3131759/index.html> accessed 4 March 2020.

${ }^{57} \mathrm{See}$, for instance, the list on the International Capital Market Association website:

<https://www.icmagroup.org/green-social-and-sustainability-bonds/sustainable-finance-initiatives/>accessed on 12 February 2020.

${ }^{58}$ For example the UK's Office for National Statistics reports a record high of $54.9 \%$ of all UK shares held by foreign investors at the end of 2018, see 'Ownership of UK quoted shares: 2018' <https://www.ons.gov.uk/economy/investmentspensionsandtrusts/bulletins/ownershipofukquotedshares/2018> accessed 28 February 2020.

${ }^{59}$ See e.g. Virgina Haufler A Public Role for the Private Sector: Industry Self-Regulation in a Global Economy (Brookings Institution Press, 2001).
} 


\section{A. Strategies for sustainable investing}

Sustainable investment, also called responsible investment or Socially Responsible Investment (SRI) is not a new phenomenon. ${ }^{60}$ It emerged in the 1960 s alongside growing opposition to apartheid in South Africa and against the background of the Vietnam War. Religious or socially oriented organisations increasingly stipulated that their investment portfolios must exclude, for example, gambling outfits, weapons manufacturers or South African business interests. ${ }^{61}$ Thus the early SRI movement was focused primarily on actively removing or choosing investments based on specific ethical guidelines. ${ }^{62}$ It has since matured and expanded into mainstream investment practice but under different labels and different strategies. ${ }^{63}$ Since around 2005 (after the UN Global Compact published its report 'Who Cares Wins' $)^{64}$ the term SRI has been somewhat overtaken by the term ESG which encompasses a wider range of strategies that aim to integrate environmental, social and governance issues into securities valuation and investment decision-making. ${ }^{65}$ Research conducted in 2019 found that ESG was almost universally top of mind for senior executives across 43 global institutional investment firms. ${ }^{66}$

From the point of view of an institutional investor, sustainable finance involves integrating ESG factors when making investment decisions, including portfolio selection and management. This is not as simple as it sounds; the Global Sustainable Investment Alliance (GSIA) counts seven distinct strategies for sustainable investing, each of which defines sustainability in a slightly different way. ${ }^{67}$ The simplest and most popular strategy (stemming

\footnotetext{
${ }^{60}$ See e.g. Lloyd Kurtz, 'Socially Responsible Investment and Shareholder Activism' in Crane et al. (eds) The Oxford Handbook of Corporate Social Responsibility (OUP 2008).

${ }^{61}$ Russell Sparkes and Christopher J. Cowton, 'The Maturing of Socially Responsible Investment: A Review of the developing Link with Corporate Social Responsibility’ (2004) 52 Journal of Business Ethics 45.

62 ibid.

63 ibid; Joakim Sandberg, Camen Juravle, Ted Martin Hedesstrom and Ian Hamilton, 'The Heterogeneity of Socially Responsible Investment' (2009) 87 Journal of Business Ethics 519.

64 'The Global Compact, Who Cares Wins: Connecting Financial Markets to a Changing World'( United Nations 2005)

<https://www.unglobalcompact.org/docs/issues_doc/Financial_markets/who_cares_who_wins.pdf >accessed 28 February 2020.

${ }^{65}$ Emile van Duuren, Auke Plantinga, Bert Scholtens, 'ESG Integration and the Investment Management Process: Fundamental Investing Reinvented' 2016 138(3) Journal of Business Ethics 525; Lauren Caplan, John S. Griswold and William F. Jarvis, From SRI to ESG: The Changing World of Responsible Investing, (Commonfund Institute September 2013); Neil. S. Eccles, and Suzette. Viviers, 'The origins and meanings of names describing investment practices that integrate a consideration of ESG issues in the academic literature' 2011104 Journal of Business Ethics 389.

${ }^{66}$ Robert G. Eccles and Svetlana Klimenko, 'The Investor Revolution' Harvard Business Review, May-June 2019 <https://hbr.org/2019/05/the-investor-revolution> accessed 12 February 2020.

${ }^{67}$ Global Sustainable Investment Alliance (GSIA), '2018 Global Sustainable Investment Review' <http://www.gsi-alliance.org/wp-content/uploads/2019/06/GSIR Review2018F.pdf>accessed 12 February 2020 .
} 
from SRI) is negative screening whereby unsavoury investments, commonly tobacco, gambling, weapons etc. are excluded from the portfolio. The GSIA estimates $\$ 19.8$ trillion funds globally are invested this way and it is the most dominant strategy in Europe. ${ }^{68}$ Integration of ESG factors into investment decision-making is the next most popular strategy at $\$ 17.5$ trillion globally, although the way in which this is done varies greatly. ${ }^{69}$ The third most used strategy globally is the use of 'corporate engagement and shareholder action' to influence corporate behaviour, at $\$ 9.8$ trillion, which is particularly popular in Japan. ${ }^{70}$ ESG is also increasingly embraced by activist hedge funds, such as Jana Partners and Trian Partners, as the fulcrum of their activist campaigns. ${ }^{71}$ Promoting ESG through shareholder engagement (and sometimes more aggressive forms of shareholder activism) corresponds most closely with the investment behaviour promoted by stewardship codes as it involves monitoring, information gathering, active voting and engagement in dialogue with investee companies. ${ }^{72}$

In general, this diversity of investment approaches demonstrates the flexible yet nebulous nature of the concept of sustainability. ${ }^{73}$ But despite some definitional uncertainty, it is very clear that sustainable investing as a whole is on the increase worldwide. In Europe total assets committed to sustainable strategies grew by $11 \%$ from 2016 to 2018 and in the United States by $38 \% .{ }^{74}$ In Australia and New Zealand a responsible approach to investing was used in relation to $63 \%$ of assets managed professionally in 2018 and in Japan, sustainable investing quadrupled between 2016 and 2018, growing from just 3\% of totally professionally managed assets in the country to $18 \% .^{75}$ Interesting in the context of stewardship is the fact that the strategy of 'corporate engagement and shareholder action' is increasing in popularity. ${ }^{76}$

\section{B. Hard law duties, reporting requirements and ESG}

As the practice of sustainable investing has become more mainstream, the question of its compatibility with the duties institutional investors owe to their clients and beneficiaries has

\footnotetext{
68 ibid

69 ibid

70 ibid, 10 and 15 .

${ }^{71}$ Charles M Nathan, On Governance: ESG Investing Takes a New Meaning for Activist Hedge Funds and Corporate Boards (The Conference Board 29 January 2019) <https://perma.cc/XGF4-6JK2> accessed on 12 February 2020. Generally, on hedge fund activism, see Dionysia Katelouzou 'Myths and Realities of hedge Fund Activism: Some Empirical Evidence’ (2013) 7 Virginia Law \& Business Review 457.

${ }^{72}$ See further Katelouzou, (n 46).

${ }^{73}$ Claire Woods and Roger Urwin, 'Putting Sustainable Investing into Practice: A Governance Framework for Pension Funds' (2010) 92 Journal of Business Ethics 1, 2.

${ }^{74}$ GSIA (n 67).

75 ibid, 4.

76 ibid.
} 
come under increased scrutiny by academics and policymakers alike. ${ }^{77}$ In most countries large institutional investors, particularly pension and investment trustees, are under a legal duty (often fiduciary in nature) to act in the best interests of their beneficiaries and clients. ${ }^{78}$ There has been much debate over the extent to which this requires investors to maximise investment returns. ${ }^{79}$ In its earlier days, SRI was seen as an investment approach that involved potential sacrifice of financial returns in order to make the world a better place. Hence investors were unclear over whether this kind of investing could breach their legal duties. ${ }^{80}$

In order to clarify the situation, in 2005 UNEP FI published a report by law firm Freshfields Bruckhaus Deringer which analysed investors' legal duties in ten jurisdictions around the world. ${ }^{81}$ The report, in what was seen as a radical decision at the time, concluded that, 'integrating ESG considerations into an investment analysis so as to more reliably predict financial performance is clearly permissible and is arguably required in all jurisdictions' (own emphasis). ${ }^{82}$ A decade later in 2015, UNEP FI launched a collaborative project, 'Fiduciary Duty in the $21^{\text {st }}$ Century' which followed up on the 2005 report, stressing that, far from being a barrier, investors' legal duties place a positive obligation on investors to integrate ESG issues. ${ }^{83}$ Country roadmaps, based on industry and expert interviews, were produced for 16 markets across the world. The project concluded with a Final report released in $2019 .{ }^{84} \mathrm{It}$

\footnotetext{
${ }^{77}$ See e.g. Benjamin J. Richardson, 'Keeping Ethical Investment Ethical: Regulatory Issues for Investing in Sustainability’ 200887 Journal of Business Ethics 555; UNEP FI, 2009, UNEP Finance Initiative Innovative Financing for Sustainability 〈https://www.unepfi.org/fileadmin/documents/unepfi_overview_2009.pdf〉 accessed 12 February 2020; Joakim Sandberg, 'Socially Responsible Investment and Fiduciary Duty: Putting the Freshfields Report into Perspective' 2011 101(1) Journal of Business Ethics 143; UK Law Commission, Fiduciary Duties of Investment Intermediaries $2014<$ https://s3-eu-west-2.amazonaws.com/lawcom-prodstorage-11jsxou24uy $7 q /$ uploads/2015/03/lc350 fiduciary duties.pdf $>$;

${ }^{78}$ For a recent account of the fiduciary duties of pension funds trustees in English law, see Anna Tilba and Arad Reisberg 'Fiduciary Duty under the Microscope: Stewardship and the Spectrum of Pension Fund Engagement' (2019) Modern Law Review 1, 11-25. On the fiduciary duties investment managers owe to clients, see Arthur B Laby, 'The Fiduciary Structure of Investment Management Regulation' in John D. Morley \& William A. Birdthistle (eds.) Research Handbook on Mutual Funds (Elgar Publishing, 2018).

${ }^{79}$ See e.g. Joakim Sandberg, '(Re-)Interpreting Fiduciary Duty to Justify Socially Responsible Investment for Pension Funds' 201321 Corporate Governance: An International Review 436.

${ }^{80} \mathrm{ibid}$; C. Juravle and A. Lewis, 'Identifying impediments to SRI in Europe: a review of the practitioner and academic literature' (2008) 17 Business Ethics: A European Review 285.

81 Freshfields Bruckhaus Deringer, A Legal Framework for the Integration of Environmental, Social and Governance Issues into Institutional Investment (UNEP Finance Initiative, October 2005), <https://www.unepfi.org/fileadmin/documents/freshfields_legal_resp_20051123.pdf>accessed 12 February 2020.

82 ibid 13.

${ }^{83}$ PRI and others Fiduciary Duty in the 21 st Century (2015) 9 <https://www.unpri.org/download?ac=1378> accessed 4 March 2020.

${ }^{84}$ PRI and others Fiduciary Duty in the $21{ }^{\text {st }}$ Century (2019) <https://www.unepfi.org/wordpress/wpcontent/uploads/2019/10/Fiduciary-duty-21st-century-final-report.pdf> accessed 4 March 2020.
} 
notes that while there was little change in the law between 2005 and 2015, there was significant change between 2015 and 2019:

Globally, there are over 730 hard and soft-law policy revisions, across some 500 policy instruments, that support, encourage or require investors to consider long-term value drivers, including ESG issues. Policy change has clarified that ESG incorporation and active ownership are part of investors' fiduciary duties to their clients and beneficiaries. ${ }^{85}$

The report divides these policy instruments into three broad categories: (i) pension fund regulations; (ii) stewardship codes; and, (iii) corporate disclosures. ${ }^{86}$ It recognises that these legal changes are often part of wider sustainable finance policy agendas. Before we move to explore how the current stewardship codes promote sustainability, we must briefly mention recent changes in reporting requirements around sustainable investing.

The mainstreaming of CSR means that most of the largest corporations in the United States produce sustainability reports on a voluntary basis and many countries in Europe and Asia (such as, China, India and Singapore) mandate corporations to disclose (material) ESG information. ${ }^{87}$ By contrast, the governance, transparency and accountability requirements placed on institutional investors (operating as specialised funds or trusts rather than listed corporations) have received sparse attention. This is now changing in the EU with the SRD II and the EU Action Plan introducing legislation to improve the disclosures of institutional investors around ESG. ${ }^{88}$ With a concerted aim to limit possible 'greenwashing, ${ }^{89}$ the EU proposed regulation will require investors to go further than just stating whether they incorporate ESG by delving into exactly how they incorporate ESG risks into investment strategy. ${ }^{90}$ Coming into force in March 2021 the EU legislation will improve coherence and

\footnotetext{
85 ibid 8.

86 ibid 13.

${ }^{87}$ The literature here is voluminous, but see, among others, Afra Afsharipour and Shruti Rana, 'The Emergence of New Corporate Social Responsibility Regimes in China and India' (2013) 14 UC Davis Business Law Journal 175; Jerry KC Koh \& Victoria Leong, 'The Rise of the Sustainability Reporting Megatrend: A Corporate Governance Perspective' (2017) 18 Business Law International 233; Constance Z Wagner, 'Evolving Norms of Corporate Social Responsibility: Lessons Learned from the European Union Directive on NonFinancial Reporting Transactions' (2018) 19 Tennessee Journal of Business Law 619; Jill E Fisch, 'Making Sustainability Disclosure Sustainable' (2019) 107 Georgetown Law Journal 923. For a list of ESG mandatory disclosure requirements across 23 countries, see Initiative for Responsible Investment, Corporate Social Responsibility Disclosure Efforts by National Governments and Stock Exchanges (2015) <http://iri.hks.harvard.edu/files/iri/files/corporate_social_responsibility_disclosure 3-27-15.pdf > accessed 4 March 2020.

${ }^{88}$ See also Part II above.

${ }^{89}$ On greenwashing see e.g. William S. Laufer, 'Social Accountability and Corporate Greenwashing' (2003) 43 Journal of Business Ethics 253.

${ }^{90}$ Proposal for a regulation on disclosures $\operatorname{COM}(2018) 354$ on disclosures relating to sustainable investments and sustainability risks and amending Directive (EU) 2016/2341.
} 
consistency across member states by bringing all professional investors under its scope - not only pension funds but hedge funds, investment managers, advisory services and insurance companies. ${ }^{91}$

The EU proposed regulation also asks investors to publish on their websites how their remuneration policy integrates ESG risks. ${ }^{92}$ This is an important development in integrating sustainability into the internal governance systems of investors that aims to improve accountability as well as transparency. Indeed, the incorporation of ESG into investment decision-making has a close parallel in the incorporation of CSR into corporate decisionmaking. To be effective, both require true integration into existing governance and remuneration systems rather than being treated as an optional add-on. ${ }^{93}$ As Woods and Urwin suggest this may involve amending the fund's overall mission and investment beliefs as well as clear leadership from fund trustees. ${ }^{94}$ In a practical sense institutional investors will need to re-train their managers and implement clear risk parameters and investment timelines. ${ }^{95}$ Just as corporate governance systems and the duties of company directors have been slowly reinterpreted to incorporate CSR, ${ }^{96}$ the governance of institutional investors and duties of fund trustees are coming under increasing scrutiny in relation to ESG. ${ }^{97}$

Thus, hard law on institutional investing and ESG, in countries where it exists, provides boundaries in relation to two issues: (i) the scope of investors' legal duties in terms of incorporation of ESG; and, (ii) the need for transparency and reporting around inclusion of ESG in investment decision-making. We see these two issues as mirroring the core objectives of current stewardship codes which aim to: (i) promote responsible asset ownership as a way to fulfil investors' duties to their clients and beneficiaries; and, (ii) encourage transparency around responsible asset ownership through stewardship policy statements and other

\footnotetext{
${ }^{91}$ ibid, Article $2 \operatorname{COM}(2018) 354$.

92 Article 4 COM(2018) 354.

${ }^{93}$ See e.g. Alice Klettner, Thomas Clarke and Martijn Boersma, 'The Governance of Corporate Sustainability: Empirical Insights into the Development, Leadership and Implementation of Responsible Business Strategy' (2014) 122 Journal of Business Ethics, 145.

${ }^{94}$ Claire Woods and Roger Urwin 'Putting Sustainable Investing into Practice: A Governance Framework for Pension Funds’ (2010) 92 Journal of Business Ethics 1-19.

95 ibid

96 Keay (n 13).

97 See e.g. Sarah Barker, Mark Baker-Jones, Emilie Barton \& Emma Fagan, 'Climate change and the fiduciary duties of pension fund trustees - lessons from the Australian law' (2016) 6(3) Journal of Sustainable Finance \& Investment 211; Magnus Jansson, Joakim Sandberg, Anders Biel \& Tommy Gärling 'Should pension funds' fiduciary duty be extended to include social, ethical and environmental concerns? A study of beneficiaries' preferences' (2014) 4 Journal of Sustainable Finance \& Investment 213.
} 
disclosures. ${ }^{98}$ However, the key question is the extent to which the stewardship codes integrate ESG and sustainability into their dual aims of responsible investment and transparency.

\section{Integration of ESG into Stewardship Codes}

Research analysing the content of stewardship codes shows that, although they all promote responsible investing and long-termism, the extent and context within which they expressly refer to ESG is very variable. ${ }^{99}$ Table 1 - based on data collected by Katelouzou and Siems confirms these earlier findings. ${ }^{100}$ From the 25 codes considered here, the overwhelming majority $(84 \%)$ refers at least once to ESG factors. Indeed, only four codes do not mention ESG factors at all (i.e. Denmark 2016, ${ }^{101}$ Korea 2016, ${ }^{102}$ Switzerland 2013, and US 2017). Several stewardship codes mention ESG only briefly in a list of many topics that investors may wish to monitor in their investee companies, ${ }^{103}$ while at the other end of the spectrum are codes that emphasise ESG integration and sustainability as a core concern for investment analysis and activity. Among them, the Code for Responsible Investing in South Africa (CRISA), published in 2011, takes the strongest stance in prioritising ESG factors, building explicitly on the PRI. ${ }^{104}$ This is but another example of the continuously evolving assemblage of norms and cross-references between different standard setters in the area of corporate governance and sustainable finance. ${ }^{105}$

\footnotetext{
${ }^{98}$ Alice Klettner 'The Impact of Stewardship Codes on Corporate Governance and Sustainability' (2017) 23 NZBLQ 259. See also Katelouzou (n 46).

${ }^{99}$ Dionysia Katelouzou 'Shareholder Stewardship: A Case of (Re)Embedding Institutional Investors and the Corporation?' in Beate Sjåfjell and Christopher M Bruner (eds) Cambridge Handbook of Corporate Law, Corporate Governance and Sustainability (CUP 2019) 581-595; Klettner (n 98).

100 Table 1 reports the relative frequencies of the words 'environmental, social and governance' or 'ESG' or 'environment and social' among 25 stewardship codes around the world. Unlike Katelouzou and Siems, we only consider current codes, with the exception of the UK where we consider both the 2012 and 2020 versions.

Focusing on relative frequencies is important because of the unequal size of the codes. For more on these 25 codes and the methodology applied (e.g. text formatting), see Dionysia Katelouzou and Mathias Siems, 'The Global Diffusion of Stewardship Codes' in Dionysia Katelouzou and Dan W. Puchniak (eds), Global Shareholder Stewardship: Complexities, Challenges and Possibilities (CUP 2021 forthcoming).

${ }^{101}$ But the Danish code does refer to CSR twice.

102 But the Korean code refers to 'non-financial' factors three times.

${ }^{103}$ See e.g. UK 2012, Australia (FSC) 2017, Italy 2016, Japan 2017, Taiwan 2016, and Singapore 2016.

${ }^{104}$ See also Natania Locke, 'Encouraging Sustainable Investment in South Africa: CRISA and Beyond' in Dionysia Katelouzou and Dan W. Puchniak (eds), Global Shareholder Stewardship: Complexities, Challenges and Possibilities (CUP 2021 forthcoming).

105 See Part II above.
} 
Table 1: ESG Consideration in Stewardship Codes Around the World

\begin{tabular}{|c|c|}
\hline Stewardship Code & $\begin{array}{l}\text { ESG consideration } \\
\text { (relative } \\
\text { frequencies) }\end{array}$ \\
\hline South Africa 2011 & $0.62 \%$ \\
\hline $\begin{array}{l}\text { Australia (ACSI) } \\
2018\end{array}$ & $0.44 \%$ \\
\hline Brazil 2016 & $0.32 \%$ \\
\hline EFAMA 2018 & $0.31 \%$ \\
\hline Kenya 2017 & $0.29 \%$ \\
\hline India (SEBI) 2019 & $0.29 \%$ \\
\hline Thailand 2017 & $0.29 \%$ \\
\hline ICGN 2016 & $0.28 \%$ \\
\hline UK 2020 & $0.23 \%$ \\
\hline India (PRDA) 2018 & $0.21 \%$ \\
\hline Canada 2017 & $0.20 \%$ \\
\hline Malaysia 2014 & $0.13 \%$ \\
\hline Hong Kong 2016 & $0.13 \%$ \\
\hline India (IRDAI) 2017 & $0.10 \%$ \\
\hline Netherlands 2018 & $0.08 \%$ \\
\hline Japan 2017 & $0.06 \%$ \\
\hline Singapore 2016 & $0.05 \%$ \\
\hline Taiwan 2016 & $0.05 \%$ \\
\hline Italy 2016 & $0.04 \%$ \\
\hline Australia (FSC) 2017 & $0.04 \%$ \\
\hline UK 2012 & $0.03 \%$ \\
\hline Denmark 2016 & $0.00 \%$ \\
\hline Korea 2016 & $0.00 \%$ \\
\hline Switzerland 2013 & $0.00 \%$ \\
\hline US 2017 & $0.00 \%$ \\
\hline
\end{tabular}

As Table 1 shows, CRISA makes the most frequent reference to ESG factors, followed by the Australia 2018 Code. Australia has two industry-based stewardship codes addressed to 
investors, one directed to asset owners (ACSI 2018) and one directed to asset managers (FSC 2017). The stark difference in the consideration of ESG-focused activities by the two Australian stewardship codes may perhaps be surprising. The Australia (FSC) 2017 Code makes very little reference to ESG-related activities as one of the several aspects of stewardship, while the Australia (ACSI) 2018 Code has sustainability as a key part of the definition of stewardship, stating, for instance: 'One way that asset owners can help protect and enhance their investments for the long term is by considering ESG matters through their stewardship practices'. ${ }^{106}$ This difference may be attributed to the institutional nature and priorities of the two issuing bodies. ${ }^{107}$ The Australia (ACSI) 2018 Code, for instance, specifically states that ' $[\mathrm{t}]$ he Australian Council of Superannuation Investors (ACSI) exists to provide a strong, collective voice on ESG issues on behalf of our members' ${ }^{108}$

Seven other codes include ESG considerations as one of the stewardship principles, even though with a varying emphasis. ${ }^{109}$ For instance, both Principle 6 of the Canadian Code and Principle 3 of the Japanese Code refer to ESG issues in the context of risk management, while Principle 2 of the Hong Kong Code encourages investors to take into account ESG issues in the context of their potential to impact on goodwill, reputation and performance. While we only consider current codes, for the UK we take into account both the 2012 and 2020 versions. ${ }^{110}$ As evidenced by the relative frequencies reported in Table 1, the 2020 revisions to the UK Code strengthened its focus on ESG. The 2020 UK Code states: '[e]nvironmental, particularly climate change, and social factors, in addition to governance, have become material issues for investors to consider when making investment decisions and undertaking stewardship'. ${ }^{111}$ In addition, the new Principle 7 of the 2020 UK Code requires asset managers and asset owners to integrate and report material ESG factors in their investment and engagement activities and explain how their decisions serve best the views and needs of their clients/beneficiaries. ${ }^{112}$ But not only national stewardship codes integrate ESG as a key

\footnotetext{
${ }^{106}$ Australian (ACSI) 2018 code, p 5. The Code is available at: https://acsi.org.au/wpcontent/uploads/2020/01/AAOSC_The_Code.pdf, accessed 6 April 2020.

${ }^{107}$ For the differences between the two codes, see Tim Bowley and Jennifer G. Hill, 'Stewardship and Collective Action: The Australian Experience' in Dionysia Katelouzou and Dan W. Puchniak (eds), Global Shareholder Stewardship: Complexities, Challenges and Possibilities (CUP 2021 forthcoming), also available <https://papers.ssrn.com/sol3/papers.cfm?abstract_id=3530402\#> accessed 6 April 2020.

108 Australia (ACSI) 2018 code, p 4.

109 These are the following codes: Brazil 2016, Canada 2017, the Netherlands 2018, Hong Kong 2016, Kenya 2017, Malaysia 2014 and Thailand 2017.

${ }^{110}$ On the previous stewardship codes, see Katelouzou and Siems (n 100).

${ }^{111}$ Financial Reporting Council, The UK Stewardship Code 2020, p 4. The code is available at https://www.frc.org.uk/investors/uk-stewardship-code, accessed 6 April 2020.

112 ibid.
} 
parameter of stewardship. Regional (EFAMA 2018) and international (ICGN 2016) codes follow this trend too.

Overall, there is a clear trend around the world to galvanise ESG-investing through stewardship codes. ${ }^{113}$ But differences in emphasis still remain which might be explained by economic, political, cultural or legal differences. ${ }^{114}$ For example, South Africa's strong focus on sustainability began in the Apartheid years, whereas Thailand and Kenya emphasise ESG in an attempt to actively attract foreign investors. ${ }^{115}$ Elsewhere where a stakeholder-focused corporate governance model is entrenched, and hard law on ESG is relatively strong, such as in the Netherlands and Denmark, stewardship codes may have less of a need to emphasise ESG. Of course, cross-country differences in the detail of investors' fiduciary or other duties may also have a role to play.

From the 25 current stewardship codes considered in this Chapter, only six codes do not mention at all the terms 'fiduciary' or 'duties'. ${ }^{116}$ But even these codes do not entirely disregard the responsibilities of investors to their ultimate beneficiaries. In some cases, this omission can be attributed to legal traits, as is the case in Denmark where investors' duties are of contractual rather than of fiduciary nature. ${ }^{117}$ Other times a different terminology is being used. For instance, the US code, despite not specifically mentioning the words 'fiduciary' or 'duties', states in principle A that:

Institutional investors are accountable to those whose money they invest. A.1 Asset managers are responsible to their clients, whose money they manage. Asset owners are responsible to their beneficiaries. A.2 Institutional investors should ensure that they or their managers, as the case may be, oversee client and/or beneficiary assets in a responsible manner. ${ }^{118}$

The highest number of references to fiduciary duties are made in the Brazilian stewardship code, followed by the Canadian code, the ICGN and the Kenyan code. For

\footnotetext{
${ }^{113}$ See also Katelouzou (n 99).

${ }^{114}$ On how such differences explain cross-country diversity in corporate governance, see Ruth V. Aguilera and Gregory Jackson, 'Comparative and international corporate governance' (2010) 4(1) The Academy of Management Annals 485.

${ }^{115}$ See Alice Klettner 'Stewardship Codes and the Role of Institutional Investors in Corporate Governance' (2021), Forthcoming.

116 These are the following codes: Denmark 2016, India (IRDAI) 2017, India (PRDA) 2018, India (SEBI) 2019, UK 2020 and US 2017.

${ }^{117}$ See Hanne S. Birkmose and Marina Bitsch 'The Danish Stewardship Code - The Past, the Present and the Future' in Dionysia Katelouzou and Dan W. Puchniak (eds.) 'Global Shareholder Stewardship: Complexities, Challenges and Possibilities', Dionysia Katelouzou \& Dan W. Puchniak, Cambridge University Press (2021, Forthcoming), also available <https://ssrn.com/abstract=3533834> accessed 6 April 2020 (explaining the contractual rather than fiduciary nature of the relevant investor duties in Denmark).

118 The US code is available at https://isgframework.org/stewardship-principles/ accessed 6 April 2020.
} 
instance, the Brazilian code states: 'The role of institutional investors cannot be separated from the fiduciary duties they assume when they become responsible for managing funds on behalf of a group of people. They are the stewards of third parties' funds'. ${ }^{119}$ These references to fiduciary or other types of investment management duties and the broader contours of accountability along the investment chain confirm the strong investment management aspect embedded in these largely voluntary codes and suggest a 'regulatory complementarity' between hard-law duties and soft-law stewardship codes. ${ }^{120}$ But from the nineteen codes that explicitly link stewardship practices to the fulfilment of investors' legal duties, only four codes (i.e. Brazil 2016, ICGN 2016, Kenya 2017 and Thailand 2017) clearly regard the consideration of ESG factors as part of institutional investors' fiduciary responsibility. The guidance to Principle 3 of the Brazilian code states:

The analysis and monitoring of ESG factors is part of the evaluation of the risks and opportunities associated with the investments, although they are not the final drivers for an investment decision. By carefully managing the assets of their end beneficiaries, institutional investors should consider relevant ESG factors as crucial aspects when it comes to the fulfillment of their fiduciary duties, being duly transparent about the way these factors will be considered. ${ }^{121}$

Also, both the ICGN Global principles and the Kenyan code consider ESG as core components of investors' fiduciary or other legal obligations, ${ }^{122}$ while the Thai code makes a clear connection between 'investment duties' and 'monitoring the investments, business and ESG performance of investee companies'. ${ }^{123}$ Principle 7 of the UK Code 2020 with its emphasis on the integration of 'stewardship and investment, including material [own emphasis] environmental, social and governance issues, and climate change' to fulfil the investors'

\footnotetext{
${ }^{119}$ AMEC (Brazilian) code, p 1. The code is available at https://en.amecbrasil.org.br/stewardship/amecstewardship-code/ accessed 6 April 2020.

${ }^{120}$ On this symbiosis of different stewardship-related rules, see Katelouzou (n 47). For earlier work on the rights and responsibilities/accountability of institutional investors, see Dionysia Katelouzou, 'Reflections on the Nature of the Public Corporation in an Era of Shareholder Activism and Shareholder Stewardship' in B. Choudhury and M. Petrin (eds.), Understanding the Company: Corporate Governance and Theory (CUP, 2017), 117-44.

${ }^{121}$ Brazilian code (n 119), p 12.

${ }^{122}$ See e.g. the ICGN code: 'This includes the consideration of wider ethical, environmental and social factors as core components of fiduciary duty' and the Kenyan code: 'In the investment context, the main focus of institutional investors is on those aspects of social, environmental and ethical practice by issuers that may pose a material commercial risk or opportunity. Attention to these sustainability issues in the investment process shall be regarded as part of an institutional investor's fiduciary responsibility to the ultimate beneficiaries'. The Code is available at https://www.icgn.org/sites/default/files/ICGNGlobalStewardshipPrinciples.pdf, accessed 6 April 2020.

${ }^{123}$ Investment Governance Code for Institutional Investors (Thai stewardship code), p 37. The code is available at https://www.sec.or.th/cgthailand/EN/Documents/ICode/ICodeBookEN.pdf accessed 7 April 2020.
} 
responsibilities to clients and beneficiaries may provide an influential blueprint for other codes to unlock sustainable finance.

These findings lead to the conclusion that even though ESG investing is increasingly becoming a core component of stewardship codes, it is not always expressly connected to fiduciary or other investment management duties. This may be attributed to legal or cultural traits and the contractual arrangements that incorporate duties of responsible investment. A more cynical explanation behind this lacking link may be the abovementioned tension between soft-law ESG-related stewardship and hard-law duties. Here the extent to which financially disadvantageous ESG decisions can be undertaken by asset managers and asset owners under the aegis of stewardship activities is very much an open question, discussed further in Part IV below. ${ }^{124}$

Before concluding this Part, it is worth considering the role of stewardship codes in improving transparency around investment decision-making. Disclosure of stewardship policies and reporting to clients and beneficiaries feature prominently in the principles of most stewardship codes around the world. Katelouzou and Siems show that from the 25 codes considered here all of them refer to the development of a disclosure policy on stewardship. ${ }^{125}$ Also, all but three codes (i.e. Australia (FSC) 2017, Singapore 2015 and US 2017) refer to reporting obligations on stewardship and voting activities. ${ }^{126}$ These can support hard law reporting requirements such as those introduced by SRD II and other efforts to improve transparency including the various voluntary initiatives referred to in Part II above. Transparency relates to the investment management aspects of stewardship and aims to increase accountability across the investment chain. ${ }^{127}$ By engaging with investee companies through formal and informal means and asking questions, ${ }^{128}$ investors facilitate information flow within and out of companies - on all matters, but increasingly on sustainability. However, whilst improving transparency around stewardship is one of the key aims of stewardship codes globally, transparency is not often expressly linked to ESG factors. Here some inspiration can be taken from CRISA which requires investors to disclose publicly a 'policy on incorporation

\footnotetext{
${ }^{124}$ On this see also Paul Davies, 'The UK Stewardship Code 2010-2020 From Saving the Company to Saving the Planet?’ in Dionysia Katelouzou and Dan W. Puchniak (eds), Global Shareholder Stewardship:

Complexities, Challenges and Possibilities (CUP 2021 forthcoming).

${ }^{125}$ Katelouzou and Siems (n 100).

126 ibid.

${ }^{127}$ For instance, the Denmark code states: [t]he stewardship code should result in increased transparency as to how the individual investor chooses to exercise stewardship activities'. On the investment management parameters of stewardship, see further Katelouzou (n 46).

${ }^{128}$ On the various facets of shareholder engagement, see ibid.
} 
of sustainability considerations, including ESG, into investment analysis and investment activities' as well as ensuring this policy is implemented. ${ }^{129}$

\section{UNLOCKING THE SUSTAINABLE FINANCE POTENTIAL OF STEWARDSHIP CODES}

Stewardship codes are but a small part of a broader network of interlocking regulatory initiatives that can directly or indirectly contribute to the promotion of sustainable finance. Despite their own set of limitations, stewardship codes, through their flexible and largely voluntary nature, can play an important role in interpreting and extending the scope of hard law. ${ }^{130}$ As discussed above in Part III, the two areas of hard law that interact most strongly with stewardship codes are investors' fiduciary duties and reporting requirements. Evidently, sustainability is not yet entirely integrated into these areas by current stewardship codes. But we are optimistic that stewardship codes have the potential to place sustainability at the core of these dual requirements. In countries where hard law on sustainability is strong, such as in Europe, stewardship codes can act as implementation guidelines. In countries where hard law is weak, either due to a strong profit maximisation culture (United States) or less developed financial markets (emerging markets of Africa and Asia) stewardship codes can help to spread best practice and have an educative effect, preparing investors for potential strengthening of hard law provisions. ${ }^{131}$ To unlock their full sustainable potential stewardship codes first need to place ESG considerations at the centre of investment practice as fundamental tenets rather than optional extras, using investors' fiduciary and other duties as a persuasive influence. They also need to encourage transparency around this integration of ESG so that information can flow to interested stakeholders. To unlock additional potential stewardship codes should try to: (i) maximise their scope and influence to encompass as much of the investment chain as possible; and, (ii) where possible extend the purpose of ESG integration beyond private financial benefit to encompass a much broader public benefit test.

\section{A. Maximising the scope and influence of stewardship codes}

The financial clout of pension funds, one of the key targeted audiences of stewardship codes, across the world is huge and if channelled in an appropriate way could make a real difference

\footnotetext{
${ }^{129}$ CRISA, Principle 5 on transparency and Principle 1 on implementation.

${ }^{130}$ On the interplays between hard and soft law in the area of stewardship, see Katelouzou (n 46).

${ }^{131}$ On the need to harden stewardship obligations, see Chiu and Katelouzou (n 51).
} 
to sustainable development. As the UK Parliamentary committee report on Greening Finance commented:

There are many hundreds of billions of pounds in UK pension schemes and these 'asset owners' sit at the top of the investment chain. The UK Sustainable Investment and Finance Association (UKSIF) argued that these 'sleeping giants' often 'do not realise the financial power they wield'. Ensuring that these funds manage environmental risks effectively could assist in the transition to a low carbon economy and reduce the UK's overall exposure to climate risk. However, only 5\% of 1,241 European Pensions schemes have considered the investment risk posed by climate change, according to the consultancy firm Mercer's 2017 European Asset Allocation Report. ${ }^{132}$

The investment industry is highly concentrated with the top ten asset managers holding $34 \%$ of externally managed assets. ${ }^{133}$ Indeed, some of these huge funds now view themselves in accordance with the theory of 'universal ownership' meaning that their holdings are so large they are vulnerable to the fortunes of the economy as a whole rather than individual companies. ${ }^{134}$ They cannot simply sell certain shares to reduce risk and thus will be more likely to monitor and engage, in other words, exercise voice rather than exit. ${ }^{135}$ This concentration of shares in the hands of institutional investors reduces the well-known managerial agency costs and arguably creates conditions more suited to stewardship behaviour. ${ }^{136}$ However, the outsourcing of asset management and other investment functions to specialist service providers can create new agency problems. ${ }^{137}$

This is where we find the sustainable finance potential of stewardship codes. They have the ability to educate and persuade these dominant players to change norms of practice and to increase transparency and awareness of how monies are invested. This is supported by the reputational benefits associated with following good stewardship practices. ${ }^{138}$ By harnessing

\footnotetext{
${ }^{132}$ UK Parliament, Greening Finance: embedding sustainability in financial decision making (6 June 2018), $<$ https://publications.parliament.uk/pa/cm201719/cmselect/cmenvaud/1063/106305.htm>accessed 28 February 2020.

${ }^{133}$ Eccles and Klimenko above (n 66).

${ }^{134}$ James Hawley. and Andrew Williams, A. 'The emergence of universal owners: Some implications of institutional equity ownership' (2000) 43(4) Challenge 43; M.J. Kiernan, M. J. 'Universal Owners and ESG: leaving money on the table?' (2007) 15(3) Corporate Governance: An International Review 478; S. Lydenberg, 'Universal Investors and Socially Responsible Investors: a tale of emerging affinities', (2007) 15(3) Corporate Governance: An International Review 467.

135 A.O. Hirschman, Exit, voice, and loyalty: Responses to decline in firms, organizations, and states (Harvard University Press 1970).

${ }^{136}$ Lucian A. Bebchuk, Alma Cohen and Scott Hirst, 'The agency problems of institutional investors' (2017) 31(3) Journal of Economic Perspectives 89.

137 ibid; Ronald J Gilson and Jeffrey N Gordon 'The Agency Costs of Agency Capitalism: Activist Investors and the Revaluation of Governance Rights' (2013) 113 Columbia Law Review 863 (arguing that the reconcentration of ownership in the hands of institutional investors gives rise to a new type of agency costs, which they call 'the agency costs of agency capitalism')

${ }^{138}$ See e.g. Davies (n 124).
} 
the power of the funds at the top of the investment chain stewardship codes can also change practices deeper in the investment chain by influencing the nature of contractual mandates. ${ }^{139}$

Of course the first step is to persuade the powerful to take action and here the great weakness of stewardship codes is their voluntary nature. ${ }^{140}$ Most apply to investors on a 'comply-or-explain' basis and for many signing up is entirely voluntary. ${ }^{141}$ This varies depending on whether the code is issued by an industry association or government regulator, but generally codes cannot force investors to engage in stewardship behaviour. We argue that this does not matter. Codes do not stand alone as a solitary lever for change, rather they form an important part of a much wider framework for investor behaviour. They can, and already are, steadily changing norms and expectations within the industry to harness the power of these huge funds. ${ }^{142}$

Nevertheless, some codes have definitely been more successful than others in gaining the attention of large investors. The UK Code, first published in 2010 by the quasi-public regulator the Financial Reporting Council (FRC) now has 178 asset managers, 103 asset owners and 12 service providers as signatories. ${ }^{143}$ At the end of 2019, the Japanese Code, issued by a government agency, had 273 signatories. ${ }^{144}$ In contrast the Australia (ACSI) 2018 Code has 16 signatories (out of its 39 members), ${ }^{145}$ the Brazilian Code issued by an industry association (AMEC) in 2016 has 19 signatories, ${ }^{146}$ and the Kenyan Code issued by the Kenya Capital Markets Authority none. ${ }^{147}$ Although these numbers are not directly comparable due to

\footnotetext{
${ }^{139}$ Klettner (n 98); Bebchuk, et al (n 136).

${ }^{140}$ Arad Reisberg, 'The UK Stewardship Code: On the Road to Nowhere?' (2015) 15 Journal of Corporate Law Studies 217; Iris H. Chiu, 'Reviving shareholder stewardship: critically examining the impact of corporate transparency reforms in the UK' (2013) 38 Delaware Journal of Corporate Law 983; Lee Roach, 'The UK Stewardship Code' (2011) 11 Journal of Corporate Law Studies 463; Brian R. Cheffins, 'The Stewardship Code's Achilles' Heel' (2010) 73 The Modern Law Review 1004.

${ }^{141}$ Further on the enforcement of stewardship codes, see Dionysia Katelouzou and Konstantinos Sergakis 'Shareholder Stewardship Enforcement' in Dionysia Katelouzou and Dan W. Puchniak (eds), Global Shareholder Stewardship: Complexities, Challenges and Possibilities (CUP 2021 forthcoming), also available <https://papers.ssrn.com/sol3/papers.cfm?abstract_id=3564266> accessed 15 April 2020.

${ }^{142}$ See e.g. the views of the CEO of Hermes Investment Management, Saker Nusseibeh, 'Stewardship: The 2020 Vision' 1 November 2019 < https://corpgov.law.harvard.edu/2019/11/01/stewardship-the-2020-vision/> accessed 16 March.

143 The list of signatories is available: https://www.frc.org.uk/investors/uk-stewardship-code/uk-stewardshipcode-statements accessed 12 February 2020.

144 The breakdown across trust banks, investment managers, insurance companies and pension funds is available at <https://www.fsa.go.jp/en/refer/councils/stewardship/20160315.html > accessed 12 February 2020.

${ }_{145}$ List available at <https://www.acsi.org.au/publications-1/australian-asset-owner-stewarshipcode.html\#Listofsig $>$ accessed 12 February 2020.

${ }^{146}$ List available at <https://en.amecbrasil.org.br/stewardship/signatories/> accessed 12 February 2020.

${ }^{147}$ See Austin Auko, 'Stewardship Code in Kenya: Is the Nigh here' in Dionysia Katelouzou and Dan W. Puchniak (eds), Global Shareholder Stewardship: Complexities, Challenges and Possibilities (CUP 2021 forthcoming).
} 
variation in market size, they provide support for research that suggests that the identity of the issuer of a code is an important factor in its effectiveness. ${ }^{148}$ As discussed in country-specific literature on stewardship, national differences in culture, governance, share ownership patterns and the interaction between stewardship codes and wider legal and regulatory frameworks will also impact on code effectiveness. ${ }^{149}$ In some countries, such as Germany and China, a path towards stewardship and sustainability is being followed without any perceived need for a stewardship code. ${ }^{150}$

Certainly, the influence of a stewardship code can be improved by strengthening the regulatory and contractual framework around it. The UK Code is the best example of a code with a level of regulatory supervision. The FRC assesses the quality of disclosure of all Code signatories and places them in tiers based on whether they report well or need to improve. ${ }^{151}$ The fact that tiering information is publicly available acts as a reputational incentive for signatories to improve. The UK Code is also a good example of how codes can gain increased influence over time: it began as an industry-based code which was then adopted by the FRC. ${ }^{152}$ In Australia, the Financial Services Council (the leading peak body for fund managers) has created a stewardship code in the form of mandatory standards for its members. ${ }^{153}$ This improves its influence through contractual rather than supervisory methods. Lastly, the code issued by European industry association, EFAMA has been amended in line with the revised

\footnotetext{
${ }^{148}$ Ruth Aguilera, Chris Florackis and Hicheon Kim, 'Advancing the Corporate Governance Research Agenda' (2016) 24 Corporate Governance: An International Review 172; J.E. Cicon, S.P. Ferris, A.J. Kammel, and G. Noronha, 'European corporate governance: a thematic analysis of national codes of governance' (2012) 18 European financial management 620. But cf Katelouzou and Siems (n 100) (finding no evidence that the identity of the issuer matters).

${ }^{149}$ See e.g. Bruno Bastos Becker, Rafael Andrade and Viviane Muller Prado, 'The Brazilian Stewardship Framework' in Dionysia Katelouzou and Dan W. Puchniak (eds), Global Shareholder Stewardship: Complexities, Challenges and Possibilities (CUP 2021 forthcoming); Locke (n 104) examining the distinctive stewardship frameworks in Brazil and South Africa respectively. For a comparative account, see Dionysia Katelouzou and Dan W. Puchniak, 'The Global Diversity of Stewardship' in Dionysia Katelouzou and Dan W. Puchniak (eds), Global Shareholder Stewardship: Complexities, Challenges and Possibilities (CUP 2021 forthcoming).

${ }^{150}$ See Wolf-Georg Ringe, 'Stewardship and Shareholder Engagement in Germany' in in Dionysia Katelouzou and Dan W. Puchniak (eds), Global Shareholder Stewardship: Complexities, Challenges and Possibilities (CUP 2021 forthcoming), also available at <https://ssrn.com/abstract=3549829 > and Lin Lin and Dan Puchniak 'Institutional Investors and Stewardship in China' in Dionysia Katelouzou and Dan W. Puchniak (eds), Global Shareholder Stewardship: Complexities, Challenges and Possibilities (CUP 2021 forthcoming) (analysing the potential of stewardship in Germany and China, respectively).

${ }^{151}$ Further on the tiering exercise, see https://www.frc.org.uk/news/november-2016/tiering-of-signatories-to-thestewardship-code accessed 7 April 2020.

${ }^{152}$ See the detailed history of the UK code, see Katelouzou (n 46). For a snapshot, see Katelouzou and Micheler (n 26).

${ }^{153}$ FSC Standard 23: Principles of Internal Governance and Asset Stewardship, July 2017.
} 
SRD II with the aim of positioning itself as a guide on how to comply with the new laws. ${ }^{154}$ There are many ways that soft law can be combined within a layered meta-regulatory regime to enhance and maximise its influence. ${ }^{155}$ Here we limit ourselves to the above examples which are merely intended to illustrate the various ways (such as through supervision and enforcement, contractual obligations etc.) to improve the sustainable potential of stewardship codes.

In terms of their scope, stewardship codes recognise the realities of the modern investment industry: heterogeneous shareholders; variation in investment strategies and the fact that asset owners often outsource fund management creating complex contractual investment chains between beneficiaries and investee companies. ${ }^{156}$ By recognising these practicalities of modern investment, stewardship codes have the potential to reach all financial intermediaries, including those who may otherwise be seen simply as service providers rather than regulated financial institutions. These intermediaries, such as broker dealers, may not be subject to legal fiduciary-style duties, yet similar duties can be placed upon them indirectly through their contractual mandates with asset owners. ${ }^{157}$ Stewardship codes can play an significant role in co-opting such important players and extending fiduciary duties and transparency (albeit in soft law) along the investment chain and thereby dealing with the agency costs of outsourcing. ${ }^{158}$

Many codes deal with improving transparency and accountability along the investment chain either through recommending disclosure of the use of service providers (such as proxy

\footnotetext{
${ }^{154}$ Susanna Rust, 'EFAMA adopts stewardship code to align with EU laws', (IPE, 31 May 2018). <https://www.ipe.com/efama-adopts-stewardship-code-to-align-with-eu-laws/10024971> accessed 12 February 2020 .

${ }^{155}$ Sharon Gilad, 'It Runs in the Family: Meta-Regulation and Its Siblings' (2010) 4(4) Regulation \& Governance 485; Christine Parker, 'Meta-Regulation: Legal Accountability for Corporate Social Responsibility' in The New Corporate Accountability: Corporate Social Responsibility and the Law, Doreen McBarnet, Aurora Voiculescu and Tom Campbell eds, (Cambridge University Press 2009); Christine Parker, The Open Corporation: Effective Self-Regulation and Democracy (Cambridge University Press, 2002); Julia Black, 'Paradoxes and Failures: "New Governance" Techniques and the Financial Crisis' (2012) 75(6) The Modern Law Review 1037; Cristie Ford, 'New Governance in the Teeth of Human Frailty: Lessons from Financial Regulation' (2010) (2) Wisconsin Law Review 441; Julia Black and Robert Baldwin, 'Really Responsive RiskBased Regulation' (2010) 32(2) Law \& Policy 181.

${ }^{156}$ See e.g. Terry McNulty and Donald Nordberg, 'Ownership, activism and engagement: Institutional investors as active owners' (2015) 24(3) Corporate Governance: An International Review 346.

${ }^{157}$ For a proposal to expand fiduciary duties on all financial intermediaries, including broker dealers, in the US, see Tamar Frankel 'Fiduciary Duties of Brokers-Advisers-Financial Planners and Money Managers' (2009) Boston University School of Law Working Paper No. 09-36) <https://ssrn.com/abstract=1446750> accessed 10 March 2020. But for a critical view on the imposition of fiduciary duties on proxy advisors, see Donna Musolli 'A Distraction in Disguise: How a Focus on Regulating the proxy-Advisory Industry Fails to Address the Unnecessary Creation of an Extra Layer of Conflict' < https://digitalcommons.law.msu.edu/king/254/> accessed 10 March 2020.

${ }^{158}$ On business outsourcing, see generally George G Geis 'Business Outsourcing and the Agency Cost Problem' (2007) 82 Notre Dame Law Review 955.
} 
advisors $)^{159}$ or by emphasising that signatories must not 'blindly delegate' their stewardship responsibilities. ${ }^{160}$ For instance, the Korean code states:

Institutional investors take on ultimate stewardship responsibilities even when they entrust all or part of their stewardship activities to external investors or other (advisory) service providers. Institutional investors should monitor and supervise to ensure that outsourced activities are executed in accordance with their own stewardship policy. Hence the Principles apply to proxy advisors, investment advisors etc. that provide (advisory) services related to the detailed contents of the Principles. ${ }^{161}$

Indeed, as powerful actors sitting at the top of a long set of relationships, institutional investors, through stewardship, have the potential to draw information upwards when it might otherwise stay hidden. Business outsourcing has become a complex problem for accountability, particularly acute in long global supply chains. ${ }^{162}$ However, suppliers increasingly have to account to listed companies, who must report to investors, who can then make better informed decisions and explain their investment strategies to beneficiaries. The incorporation of ESG information into this flow of data has great potential in improving sustainability across the economy. Indeed, in 2019 UNEP FI announced a new collaboration with the PRI and law firm Freshfields Bruckhaus Deringer to explore the wider legal framework around investing for sustainability impact. ${ }^{163}$ It is likely that rules around providing financial advice as well as variation in the fiduciary duties of different categories of investors and intermediaries will come under more scrutiny in future in terms of their incorporation of sustainability considerations.

\section{B. Moving ESG away from a pure financial business case}

Normalising the integration of ESG into investors' legal duties to clients and beneficiaries may pave the way for extending those duties beyond the immediate business case. ${ }^{164}$ At present, most jurisdictions still place an overriding financial priority on 'the best interests of beneficiaries'. ${ }^{165}$ Until now, the mainstream approach has been that ESG factors can and

\footnotetext{
${ }^{159}$ See, for example Malaysian code para 6.6, Thailand code Principle 5.5, UK code Principle 6,

${ }^{160}$ Klettner (n 98) 265. See for example the Hong Kong Code at 1; and the Japanese code at 11.

${ }^{161}$ Korean code, p 2, para 2.

${ }^{162}$ See e.g. Kishanthi Parella, 'Outsourcing Corporate Accountability' (2014) 89 Washington Law Review 747.

${ }^{163}$ See <https://www.unepfi.org/news/industries/investment/groundbreaking-work-to-assess-real-worldsustainability-impact-for-investors/> accessed 12 February 2020.

164 See Part III B above.

${ }^{165}$ For example, Australian legislation requires trustees to maintain pension funds solely for the provision of retirement benefits; in Germany best interests are defined in a financial sense whilst taking into account risks; and in the UK the primary concern of trustees must be to generate appropriate risk adjusted returns - see UNEPFI, 'Fiduciary Duty in the $21^{\text {st }}$ Century' (2015).
} 
should be incorporated, but the purpose of this is to promote long-term financial gains and mitigate long-term risks. In other words, ESG factors cannot be considered solely for reasons of ethics or justice.

The situation changes if end-beneficiaries give express permission to their pension fund to invest based on ethics. However, this may be seen as a risky move unless precise boundaries are drawn. This is not impossible and is why the EU is focusing on financial advisors and the advice and information that institutional investors, including asset managers, insurance companies and investment or insurance advisors give to clients and fund beneficiaries. ${ }^{166}$ The only person who can really decide what is in their long-term best interests is the fund beneficiary him/herself. Many people might be focused on maximal financial returns, but many will not, especially if accurately informed of the potential social and environmental harm this could cause. Research based in Sweden has found that beneficiaries on average prefer their pension funds to go beyond financial concerns and engage in SRI. ${ }^{167}$ In the UK there is also evidence of changing consumer preferences:

There is evidence that demand for sustainable investment is growing, with young people driving this trend. In 2017 40\% of those surveyed in an annual YouGov poll for 'Good Money Week' wanted a 'fossil fuel free' pension option, up from 35\% in 2016 and $32 \%$ in 2015 . In the 2017 poll, over half of 18 to 34 -years-olds (54\%) said they would like to be offered fossil free investments as standard, compared to the national average of $40 \%$, and only $34 \%$ of those over 55 . Overall, $57 \%$ of the UK public with a pension believe investment managers have a responsibility to ensure holdings are managed in a way that is positive for society and the environment, according to the survey. ${ }^{168}$

Investors cannot be given free rein to use pension monies to subjectively 'do good' in the world and thus we need to find a way to define and account for social and environmental benefit and/or harm. Richardson refers to social accounting and sustainability indicators as potential tools for this. ${ }^{169}$ The EU Taxonomy is likely to provide a good start in terms of technical standards for defining sustainable economic activities. ${ }^{170}$ This could ultimately be supported

\footnotetext{
166 The Commission has solicited feedback on amendments to delegated acts under the Markets in Financial Instruments Directive (MiFID II) and the Insurance Distribution Directive.

${ }^{167}$ Magnus Jansson, Joakim Sandberg, Anders Biel \& Tommy Gärling 'Should pension funds' fiduciary duty be extended to include social, ethical and environmental concerns? A study of beneficiaries' preferences' (2014) 4 Journal of Sustainable Finance \& Investment 213.

${ }^{168}$ House of Commons Environmental Audit Committee, Greening Finance: embedding sustainability in financial decision making (HC 1063 2018) 17, para 37. <https://publications.parliament.uk/pa/cm201719/cmselect/cmenvaud/1063/106305.htm\#_idTextAnchor025> accessed 4 March 2020.

${ }^{169}$ Richardson (n 77).

${ }^{170}$ See Part IIB above.
} 
by changes to investors' legal duties to their clients and beneficiaries that incorporate an underlying public interest or sustainable development test. ${ }^{171}$ Lydenberg explains that investors are pulled in opposite directions by two powerful streams of intellectual thought, the legal and economic. ${ }^{172} \mathrm{He}$ argues that modern finance has permitted economic 'rationality' (efficient, private value-maximisation) to downplay the importance of legal 'reasonableness' (wisdom, discretion and consideration of one's impact on the world). The potential of stewardship codes is in providing the foundations for increased consumer awareness of how funds are being invested. This has yet to be generally achieved. The UK Code 2020, for instance, has been less ambitious compared to its $2019 \mathrm{draft}^{173}$ and instead of talking of 'sustainable value', it refers to the creation of 'long-term value for clients and beneficiaries leading to sustainable benefits for the economy, the environment, and society'. ${ }^{174}$

\section{CONCLUSION}

Stewardship codes must be viewed as an influential part of the overall legal framework that applies to institutional investors. Their role is not to single-handedly change investment behaviour but to act as one of many mutually reinforcing regulatory instruments pursuing common 'good' goals. These regulatory instruments include some of the international initiatives referred to above as well as binding and non-binding national laws that impact on investor behaviour.

While we are not blind to the limitations the investment management business models pose on stewardship, ${ }^{175}$ we are optimistic that as well as encouraging active, long-term ownership stewardship codes have the potential to place ESG and sustainability firmly within the scope of investors' fiduciary and other duties helping to cement modern interpretation of long-standing legal obligations. ${ }^{176}$ To fully unlock their potential when it comes to sustainability, it is important that stewardship codes take a strong stance on the incorporation of ESG factors as a central element of investment practice. Many codes have already done this,

\footnotetext{
${ }^{171}$ Richardson (n 77) 566; Dirk Schoenmaker and Willem Schramade, Investing for long-term value creation' (2019) 9(4) Journal of Sustainable Finance \& Investment 356.

172 Steve Lydenberg, 'Reason Rationality and Fiduciary Duty' (2014) 119 Journal of Business Ethics 365.

${ }^{173}$ FRC, Consulting on a revised UK Stewardship Code (30 January 2019),

<https://www.frc.org.uk/consultation-list/2019/consulting-on-a-revised-uk-stewardship-code > accessed 11

March 2020.

${ }^{174}$ See also Davies (n 124).

${ }^{175}$ See Roger M. Barker and Iris H.-Y. Chiu, 'Investment Management, Stewardship and Corporate Governance Roles' in in Dionysia Katelouzou and Dan W. Puchniak (eds), Global Shareholder Stewardship: Complexities, Challenges and Possibilities (CUP 2021 forthcoming) as well as Davies (n 124) chapters.

176 James P. Hawley, Keith L. Johnson and Edward J. Waitzer, 'Reclaiming Fiduciary Duty Balance' (2011)

4(2) Rotman International Journal of Pension Management 4.
} 
but others need to be much clearer about the way in which investors' legal duties and ESG support each other. ${ }^{177}$ When hard law leaves actors with a level of discretion, soft law has an important influencing role around the way actors exercise that discretion. ${ }^{178}$ Within the wider framework of increased reporting requirements and heightened awareness of environmental and social threats, stewardship codes have the potential to strengthen the links between civil society and business. ${ }^{179}$ With the support of the interlocking regulatory framework emerging to govern sustainable finance, stewardship codes can bring the public, 'reasonable man'180 viewpoint back into financial decision-making. This will be particularly important as we assess the social and financial impacts of the Covid-19 pandemic and navigate a path to recovery.

\footnotetext{
${ }^{177}$ Klettner (n 98).

${ }^{178}$ Cary Coglianese and Evan Mendelson 'Meta-Regulation and Self-Regulation' in Cave, Baldwin and Lodge (eds) The Oxford Handbook on Regulation (OUP 2010).

179 Jonathan D. Raelin and Krista Bondy, 'Putting the Good Back in Good Corporate Governance: The Presence and Problems of Double-Layered Agency Theory' (2013) 21(5) Corporate Governance: An International Review 420.

${ }^{180}$ Lydenberg (n 172).
} 


\section{about ECGI}

The European Corporate Governance Institute has been established to improve corporate governance through fostering independent scientific research and related activities.

The ECGI will produce and disseminate high quality research while remaining close to the concerns and interests of corporate, financial and public policy makers. It will draw on the expertise of scholars from numerous countries and bring together a critical mass of expertise and interest to bear on this important subject.

The views expressed in this working paper are those of the authors, not those of the ECGI or its members. 


\section{ECGI Working Paper Series in Law}

\section{Editorial Board}

Editor

Consulting Editors

Editorial Assistant
Amir Licht, Professor of Law, Radzyner Law School, Interdisciplinary Center Herzliya

Horst Eidenmüller, Freshfields Professor of Commercial Law, University of Oxford

Martin Gelter, Professor of Law, Fordham University School of Law

Geneviève Helleringer, Professor of Law, ESSEC Business

School and Oxford Law Faculty

Curtis Milhaupt, Professor of Law, Stanford Law School

Niamh Moloney, Professor of Law, Department of Law, London

School of Economics and Political Science

Úna Daly, ECGI Working Paper Series Manager 


\section{Electronic Access to the Working Paper Series}

The full set of ECGI working papers can be accessed through the Institute's Web-site (https://ecgi.global/content/working-papers) or SSRN:

Finance Paper Series http://www.ssrn.com/link/ECGI-Fin.html

Law Paper Series http://www.ssrn.com/link/ECGI-Law.html 